\title{
Multiple n-words in Afrikaans
}

\author{
Kate van Gass \\ Department of General Linguistics, Stellenbosch University, 7600, Stellenbosch, South Africa \\ E-mail: katevg@sun.ac.za
}

\section{Introduction}

When two elements of negation are present in a given syntactic domain, two different situations may arise: either (i) the two negative elements may cancel each other out, a situation referred to as "double negation", or (ii) the two negative elements may constitute, together, a single instance of negation, referred to as "negative concord" (a term coined by Labov 1972). Afrikaans is a language that closely resembles Dutch and German in that the finite verb appears in second position in subject-initial main clauses and in final position in embedded clauses. Unlike Standard Dutch and Standard German, however, Afrikaans exhibits negative concord ${ }^{1}$.

Afrikaans generally requires two negative elements to occur in a negative clause. For example, in sentence (1) negation is expressed by two seemingly identical negative elements, a sentence-medial nie $e_{1}$ and a sentence-final nie $_{2}$, while in sentence (2) negation is expressed by nooit, an n-word ${ }^{2}$ (a term coined by Laka 1990), and the sentence-final nie $e_{2}$. In colloquial varieties of Afrikaans, however, it is also possible to find a single negation expressed by more than one n-word and the sentence-final nie 2 , as in sentence (3). The English translations of these sentences show that Afrikaans exhibits negative concord and not double negation. 
(1) Haar suster het nie $_{1}$ haar verjaarsdag vergeet nie $_{2}$.

her sister have not her birthday forgotten NEG

"Her sister didn't forget her birthday."

(2) Hy het nooit sy broer vergewe nie $_{2}$.

he have never his brother forgiven NEG

"He never forgave his brother."

(3) Ek het niemand nooit daar gesien nie $_{2}$.

I have nobody never there saw NEG

"I never saw anybody there."

Initially a rather neglected field of research in generative linguistics, there has been a recent increase in attention paid to negation in Afrikaans ${ }^{3}$, although the focus has largely been restricted to the so-called "double nie". Very little mention has been made of the possibility of more than one n-word occurring together with sentence-final nie $e_{2}$, as is the case in more traditional negative concord languages such as Standard French or Italian. This paper aims to provide an empirically-based description of Afrikaans negation with specific reference to cases where multiple n-words occur together with the sentence-final nie $e_{2}$ in negative concord constructions. The paper is organised as follows: section 2 provides a definition of the phenomenon in question, section 3 presents the empirical data, section 4 critically examines two proposed analyses of the phenomenon and provides an assessment of what is needed to account for the Afrikaans data, while section 5 concludes the paper.

\section{Negative doubling and negative spread}

When working with languages that exhibit negative concord, one can distinguish between two forms of negative concord, namely negative doubling and negative spread (Den Besten 1986). Negative doubling refers to the scenario in which the sentential negative marker occurs in all sentences that contain an n-word, as illustrated by sentence (2) above and by the French sentence in (4), while negative spread refers to the scenario in which the negative feature is 
"spread" or distributed over any number of indefinite expressions in the sentence, as illustrated in sentence (5).

(4) Je n'ai vu personne.

I NEG-have seen nobody

"I haven't seen anybody."

(5) Personne n'a rien dit.

nobody NEG-has nothing said

"Nobody has said anything."

According to Giannakidou (2000: 460), negative spread co-exists with negative concord proper (as in the Standard French examples above) and is also found marginally in languages that typically do not exhibit negative concord, such as Dutch and German, as example (6) illustrates.

(6) Ik heb nooit geen problemen met haar gehad.

I have never no problems with her had

"I have never had any problems with her."

Zeijlstra (2006) notes that although these constructions, in which two negative elements yield one single semantic negation, are considered (prescriptively) to be ungrammatical in Dutch, they are found in many non-standard varieties. According to Zeijlstra, these constructions always have an emphatic reading and, for this reason he labels them "Emphatic Multiple Negative Expressions" (EMNE's). He holds that EMNE's are not instances of negative spread as they are fundamentally different from negative concord constructions and occur in languages that do not display negative concord. In fact, he argues that EMNE's are a result of the disappearance of negative concord in Dutch. Zeijlstra's proposal, as it relates to Afrikaans, will be considered in section 4, in light of the discussion below and the data presented in section 3. 
In previous studies of negation (cf. Den Besten 1986; Van der Wouden and Zwarts 1993; Van der Wouden 1994; Hoeksema 1997) it has been proposed that Afrikaans is a language that displays only negative doubling but no negative spread. This is certainly the case for Standard Afrikaans, where (prescriptive) judgements indicate that sentences containing more than one n-word are ungrammatical on a negative concord interpretation. However, consider the sentences in (7) and (8) below, provided by De Stadler (1989: 281). De Stadler notes that in these cases, which according to him are restricted to informal, spoken varieties of Afrikaans, the multiple n-words are not used to express a positive value (i.e. double negation), but rather to emphasise the negative value of the sentence.

(7) Jy vertel my ook nooit niks nie you tell me also never nothing NEG "You also never tell me anything."

(8) Niemand het niks gedoen nie 2. nobody have nothing done NEG "Nobody did anything."

In his discussion of colloquial negative forms in Afrikaans, Donaldson (1993: 409), in turn, notes that niks and $g^{\prime} n$ can replace nie ${ }_{1}$ for emphasis, and that sentences such as those in (9) and (10) are also possible ${ }^{4}$. He notes that these constructions are both colloquial and emphatic. De Stadler (1989: 283) makes the same observation in his discussion of $g^{\prime} n$, which, according to him, is an emotively stronger form of nie $e_{1}$, noting that in sentences like (9) where $g^{\prime} n$ occurs with the negative degree word niks, $g^{\prime} n$ cannot be substituted with nie $_{1}$ if the sentence is to maintain its negative value.

\section{(9) Hy wil g'n niks luister nie 2.}

he will no nothing listen NEG

"He will not listen at all." 
(10) Jy gaan met hierdie ding g'n nêrens kom nie 2. you go with this thing no nowhere come NEG "You won't get anywhere at all with this thing."

What is also interesting here is that the use of niks in sentence (9) is in itself colloquial. If $g^{\prime} n$ is removed from both sentences, as in (11) and (12) below, sentence (11) remains colloquial while sentence (12) becomes an acceptable sentence in Standard Afrikaans. In order to remove the colloquial nature of (11), one would have to replace niks with nie ${ }_{1}$.

(11) Hy wil niks luister nie $e_{2}$

he will nothing listen NEG

"He will not listen."

(12) Jy gaan met hierdie ding nêrens kom nie ${ }_{2}$.

you go with this thing nowhere come NEG

"You won't get anywhere with this thing."

From the data provided in this section, it should be clear that Afrikaans does indeed display multiple n-word constructions with a negative concord reading. In the following section data collected in a corpus study and through native speaker judgements will be presented. These data will inform the critical examination (presented in section 4) of two proposed analyses of multiple n-words in negative concord constructions as they relate to Afrikaans.

\section{Data}

\section{Corpus data}

A corpus study was undertaken to determine the prevalence of multiple n-word combinations in written Afrikaans. The corpus data used to inform the study consisted of utterances found in newspaper articles accessed through the public access Media24 archive (the on-line database of the NasPers newspaper group). The Media24 database currently contains more than 3500000 Afrikaans newspaper articles. The archive is primarily intended to enable searches for articles related to specific topics, using so-called content words as search items, 
however the archive search tools were adjusted for the duration of the data collection in order to allow searches using so-called stop words, such as n-words and nie.

An initial search was undertaken for individual n-words in Afrikaans, with the results shown in figure 1. Unfortunately these are not necessarily accurate counts of the number of instances of each specific word, as firstly, articles may contain more than one instance of each word, which would only be counted as one instance, and secondly, some articles are duplicated on the system and so an instance of a specific word in one article may be counted more than once if there is more than one copy of the article in the database ${ }^{5}$. However these results are still useful when one considers the numbers presented in figure 1 relative to each other.

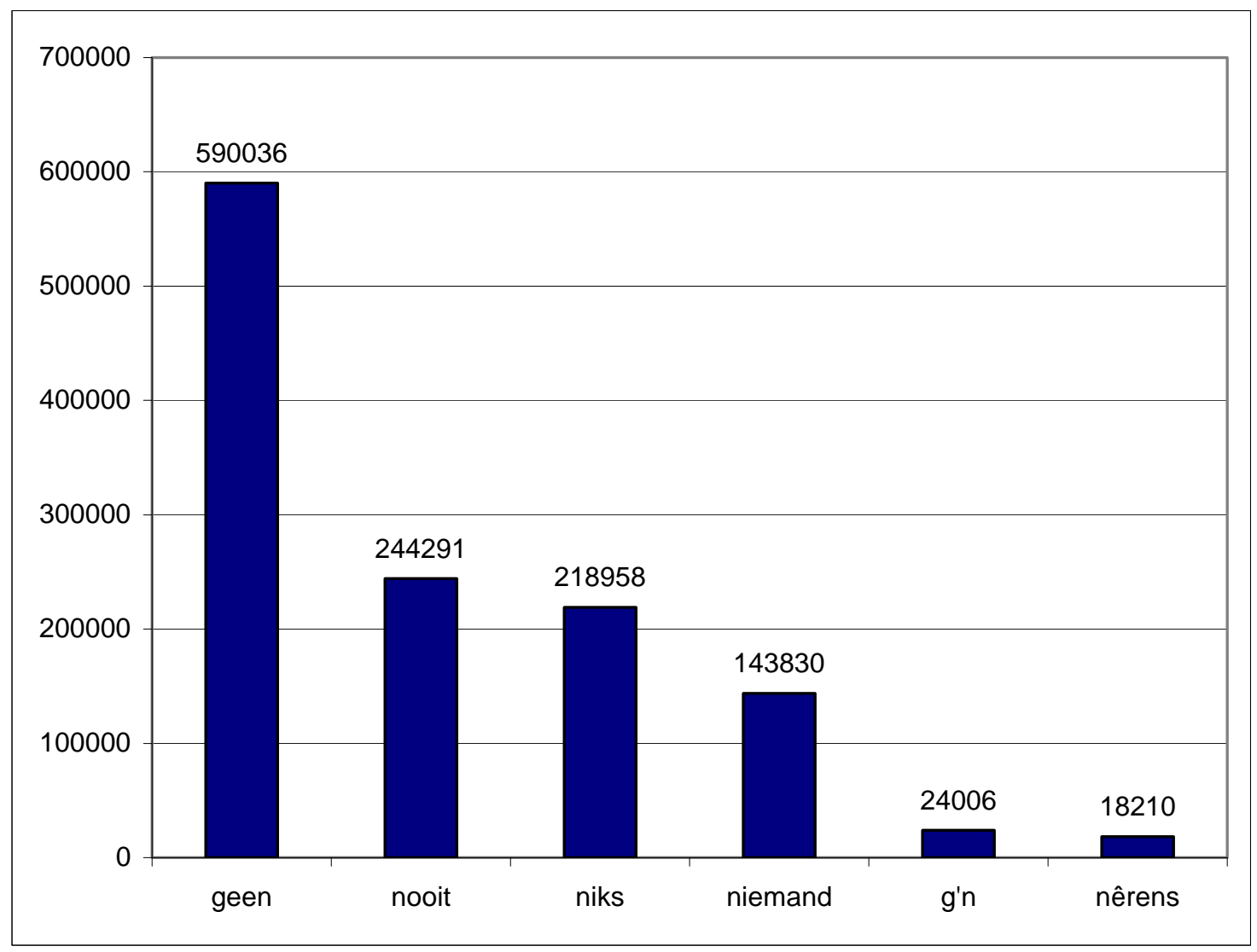

Figure 1. Total number of articles containing n-words

What is interesting to note in these results is the extraordinarily high occurrence of geen in comparison to the other n-words. This item occurs nearly three times as often as the next most common n-word, nooit. One possible reason for this pattern is the fact that geen is a negative 
determiner, which entails that it is likely to occur far more often than the nominal and adverbial n-words. A second interesting observation is that $g^{\prime} n$, which is considered an interchangeable variant of geen, occurs in a relatively large number of articles (more in fact than the n-word nêrens), despite it's strong colloquial nature. What this appears to indicate is that despite newspapers being a written medium, and, by extension, containing largely standardised language use, there is a certain amount of colloquial language use that occurs ${ }^{6}$.

After the initial search for n-words, a subsequent search for specific combinations of n-words was undertaken. After checking all articles for duplication, i.e. ensuring that no article occurred more than once, and for instances where two adjacent n-words belonged to two separate sentences, the results shown in figure 2 were noted. One hundred and fifty-seven instances of $g^{\prime} n$ niks were found, by far the highest total for an n-word combination, and interesting when one considers that $g^{\prime} n$ is the second lowest occurring n-word. Interestingly, the second-highest occurring n-word combination, g'n niemand, also contains $g^{\prime} n$, and together these two n-word combinations make up two-thirds of the n-word combinations found. As mentioned before, $g$ ' $n$ is not a standard written form, so it is quite surprising to find it in written (non-quoted) material, although, as will be seen from the various examples that follow, the instances where n-word combinations, such as $g^{\prime} n$ niks, occur tend to be in less formal types of newspaper discourse, such as sports reports and readers' letters.

Of the other eight n-word combinations only niemand niks and nooit niks appear more than ten times in the data (niemand niks appears 31 times and nooit niks appears 28 times). However this is not surprising considering the highly colloquial nature of n-word combinations. In (13) to (24) below, examples of the n-word combinations listed in figure 2 are presented, all from articles in the Media24 archive. 


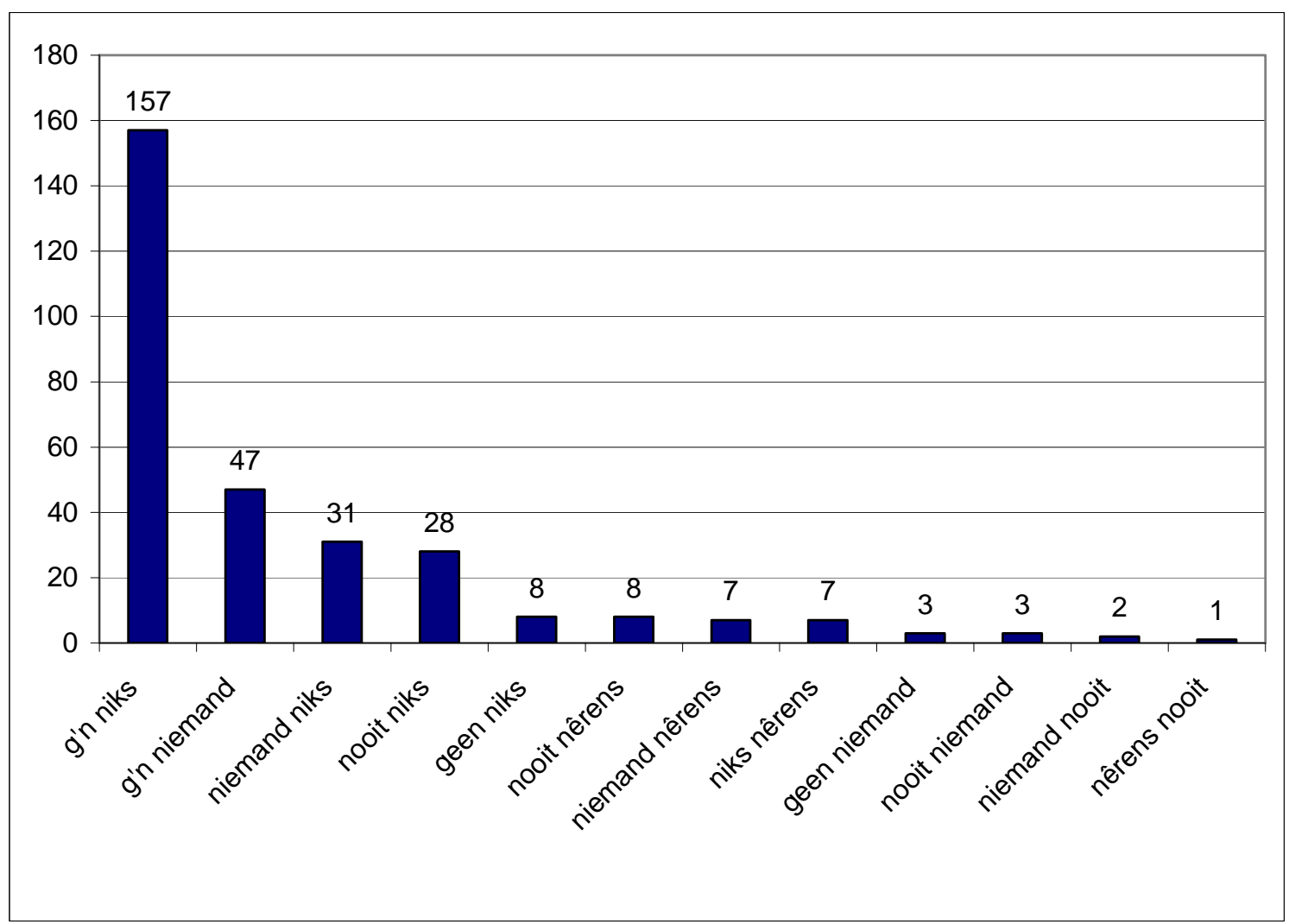

Figure 2. Total number of n-word combinations

(13) Ons het g'n niks deure vir Nicholis Louw oopgemaak nie 2. we have no nothing doors for Nicholis Louw open-made NEG "We opened no doors for Nicholis Louw."

(Rapport 2005-11-27)

(14) "Dié span van my staan vir g'n niemand terug nie $e_{2}$, het mnr. Walker trots gesê. this team of mine stands for no nobody back NEG have Mr Walker proudly said "'This team of mine stands back for no-one,' said Mr Walker proudly."

(Beeld 2001-01-29)

(15) Daarom sê ek, ons skuld niemand niks nie $e_{2}$ ! therefore say I we owe nobody nothing NEG "Therefore I say that we owe nobody anything!" 
(16) Ons hoor nooit niks van die polisie nie.

we hear never nothing from the police NEG

"We never hear anything from the police."

(Beeld 2004-02-24)

(17) Ek het geen stokperdjies, geen meisies, geen niks nie 2.

I have no hobbies no girlfriends no nothing NEG

"I have no hobbies, no girlfriends, nothing."

(Die Burger 1998-05-11)

(18) Ons is nog nooit nêrens betrap nie 2.

we are yet never nowhere trapped NEG

"We have never been trapped anywhere."

(Volksblad 2002-01-19)

(19) En bowe-al futiel, omdat dit niemand nêrens bring nie ${ }_{2}$. and above-all futile because it nobody nowhere brings NEG "And above-all futile, because it gets nobody anywhere."

(Beeld 1997-02-07)

(20) Ek het nog niks nêrens geteken nie ${ }_{2}$, maar my kontrak met Natal verstryk I have yet nothing nowhere signed NEG but my contract with Natal expires begin Januarie.

beginning January

"I haven't signed anything yet, but my contract with Natal expires at the beginning of January."

(Rapport 1999-01-03)

(21) "Teen aanstaande Mei gaan min groot Amerikaanse maatskappye teenwoordig wees in by next May go few large American companies present be in Suid-Afrika en oor twee jaar geen niemand meer daar wees nie ${ }_{2}$," het mnr. Patrick South Africa and over two years no nobody more there be NEG have Mr Patrick 
McVeigh gister gesê.

McVeigh yesterday said

"'By the end of next May there will be very few large American companies present in South Africa, and in two years' time there will be no-one at all there anymore,' said Mr Patrick McVeigh yesterday."

(Die Burger 1986-10-24)

(22) Warne en Muralitharan het reeds gewys daar was nog nooit niemand beter Warne and Muralitharan have already shown there was yet never nobody better as hulle nie $_{2}$. than them NEG

"Warne and Muralitharan have already shown that there was never anybody better than them."

(Rapport 2006-06-11)

(23) Ek het niemand nooit aangesê om te lieg nie 2.

I have nobody never to-said to lie NEG

"I have never told anybody to lie."

(Volksblad-1998-08-17)

(24) Julle is nêrens nooit meer veilig nie 2. you are nowhere never more safe NEG "You are never safe anywhere anymore."

(Die Burger 2003-12-24)

The majority of the examples above, and indeed the majority of all the instances of multiple n-word constructions found in the data clearly come from sports reports and from readers' letters to the various newspapers. Both of these types of news discourse are more colloquial in nature than more formal news reports and editorials. These data therefore confirm the observations of De Stadler (1989) and Donaldson (1993), and the intuitions of native speakers of Afrikaans, that multiple n-word constructions only occur in informal, colloquial speech. 


\section{Native speaker judgements}

In order to supplement the findings of the corpus study, a sentence judgement study was undertaken to elicit native speaker judgements for 15 Afrikaans sentences containing multiple n-words ${ }^{7}$. The study took the form of an on-line questionnaire, administered via WebCT, the web-learning environment at Stellenbosch University. The participants were 48 undergraduate students registered for either General Linguistics or Afrikaans and Dutch. Participants were asked to judge the acceptability of a sentence, and to indicate the meaning of each sentence that they found acceptable. Questions were delivered to the participants one by one, and participants were unable to revisit questions they had already answered. No time limit was placed on the questionnaire, but participants were asked to use their intuitions and not spend more than 10 seconds on each question. An example of the questions asked in the questionnaire is given in figure 3 . The test sentences were selected to be representative of the possible multiple n-word combinations in Afrikaans, and were largely based on the data collected in the corpus study. These sentences are given in (25) to (39) below.

47. (Points: 0)

Is dit aanvaarbaar vir 'n Afrikaanssprekende om die volgende te sê? Indien wel, dui dan in die volgende vraag aan wat die sin beteken.

\section{Hulle het g'n niemand gehelp nie}

1. Ja

2. Nee

3. Nie seker nie

\section{Save Answer}

48. (Points: 0)

Beskou weer die voorbeeld sin by die vorige vraag:

\section{Hulle het g'n niemand gehelp nie}

Indien hierdie sin aanvaarbaar is, gee 'n aanduiding van wat dit beteken.

a. Hierdie sin is nie aanvaarbaar vir 'n Afrikaanssprekende nie.

b. Dit beteken dat hulle geeneen gehelp het nie.

c. Dit beteken dat hulle wel iemand gehelp het.

d. Dit kan enige een van hierdie betekenisse hê, afhangende van die konteks.

\section{Save Answer}

Figure 3. Sample questions from pilot study questionnaire ${ }^{8}$ 
(25) Hulle het g'n niemand gehelp nie 2 .

they have no nobody helped NEG

"They didn't help anybody."

(26) Dit is g'n niks lekker nie.

it is no nothing nice NEG

"It is not at all nice."

(27) Ek is vir g'n niemand of g'n niks bang nie.

I am for no nobody or no nothing scared NEG

"I am not scared of anybody or anything."

(28) G'n niemand het hulle g'n niks gevra nie ${ }_{2}$.

no nobody have them no nothing asked NEG

"Nobody asked them anything."

(29) Hy vra niemand niks nie 2.

he asks nobody nothing NEG

"He doesn't ask anybody anything."

(30) Hy vra vir niemand niks nie.

he asks for nobody nothing NEG

"He doesn't ask anybody anything."

(31) Hulle het niemand niks gehelp nie 2. they have nobody nothing helped NEG

"They didn't help anybody at all."

(32) Hulle het niks niemand gehelp nie 2 .

they have nothing nobody helped NEG

"They didn't help anybody at all." 
(33) In die groot stad is niemand nêrens veilig nie ${ }_{2}$.

in the big city is nobody nowhere safe NEG

"In the big city, nobody is safe anywhere."

(34) Hy het gesê dat ons niemand nêrens sal vind nie ${ }_{2}$. he have said that we nobody nowhere will find NEG "He said that we won't find anybody anywhere."

(35) Hy het gesê dat ons nêrens niemand sal vind nie ${ }_{2}$. he have said that we nowhere nobody will find NEG "He said that we won't find anybody anywhere."

(36) Hulle het nooit niemand gehelp nie 2 . they have never nobody helped NEG "They never helped anybody."

(37) Ek het niemand nooit daar gesien nie 2 . I have nobody never there seen NEG "I never saw anybody there."

(38) Ons het nooit nêrens gegaan nie 2. we have never nowhere went NEG "We never went anywhere."

(39) Ons het nêrens nooit gegaan nie 2. we have nowhere never went NEG "We never went anywhere."

The graph in figure 4 shows the results of the study. As can be seen, there was a great deal of variation in the percentage of participants who found the various sentences acceptable. Not a single sentence was judged acceptable by $100 \%$ of the participants, which is perhaps an indication of the non-standard nature of these constructions. Because this study involves 
judging written sentences, non-standard, colloquial constructions are more likely to be judged unacceptable, even if they are prevalent in the spoken variety. Murphy (1997), in her study on the effect of modality on L2 grammaticality judgement tasks, notes that modality influences accuracy on ungrammatical sentences, as subjects are less accurate at judging spoken sentences than written sentences. The importance of this study is the clear indication it gives that subjects respond differently in a grammaticality judgement task when the sentences are presented in different modalities (Murphy 1997: 55). The fact that the constructions in this study were presented in the written modality is therefore bound to affect the participants' judgements of what is clearly a spoken-language or non-standard construction. In order to elicit potentially more reliable judgements, or at least less prescriptive judgements, it is essential that future research is structured so as to solicit native speaker judgements of sentences presented in both the visual and aural modality.

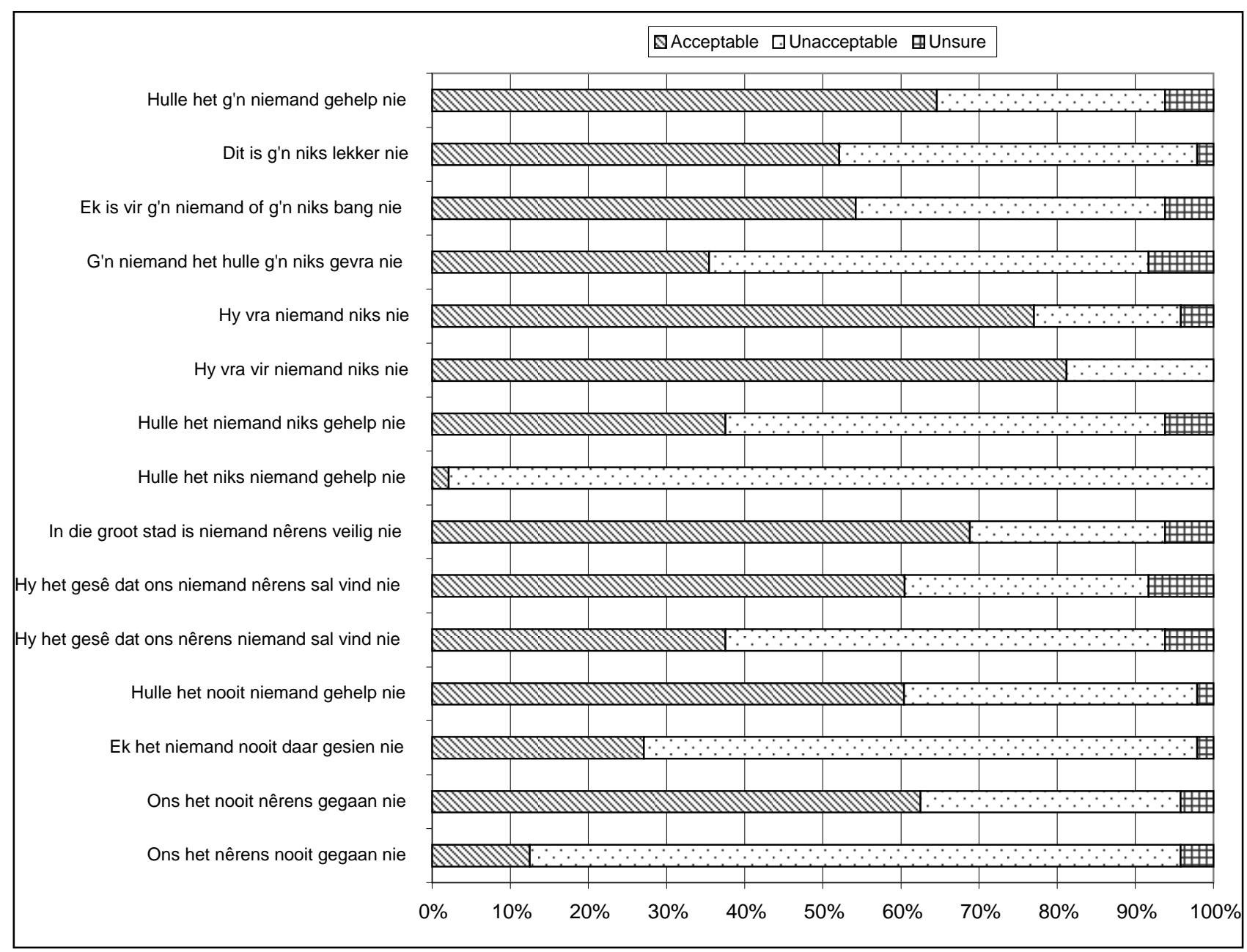

Figure 4. Participants' responses to questionnaire 
The two sentences, sentences (29) and (30), that scored highest, i.e. were found acceptable by the largest percentage of participants (77\% and $81 \%$ respectively), both contain the combination niemand niks. Recall that this is also the construction that was found most frequently, after the two combinations with $g^{\prime} n$, in the corpus data. The third sentence that contains the combination niemand niks, sentence (31), was judged acceptable by only a third of the participants (37.5\%). This striking difference from the percentages for sentences (29) and (30) is likely to be a result of the fact that, as with sentence (9) in section 2, the word niks is itself used in a colloquial manner, as a replacement for nie $e_{1}$. Interestingly, sentence (32) which also contains niemand and niks, but with the inverted order - niks niemand - was judged unacceptable by almost all of the respondents. This pattern was also noted for sentence (35), which contains the inverted combination nêrens niemand, as opposed to the more acceptable combination niemand nêrens as found in sentence (34); sentence (37), with the inverted combination niemand nooit, rather than the more acceptable combination nooit niemand as in sentence (36); and sentence (39), with the inverted combination nêrens nooit, rather than the more acceptable combination nooit nêrens as in sentence (38).

Finally, if we look at the sentences which contain $g^{\prime} n$ we see an interesting pattern. Sentence (25), which contains the combination $g^{\prime} n$ niemand, is judged acceptable by the majority of participants. However sentence (26), which contains the combination $g^{\prime} n$ niks and sentence (27), which contains both $g^{\prime} n$ niemand and $g$ 'n niks, are judged acceptable by only half of the participants, and sentence (28), which is nearly identical to sentence (27), is judged acceptable by only a third of the participants. This pattern could potentially be explained by the colloquial use of $g^{\prime} n$ and niks and, hence, the non-standard nature of these constructions. In sentence (26), for example, niks is used in the same colloquial way as it is used in sentence (31). As has been mentioned above, the fact that these sentences were all presented in the written modality may have influenced participants' acceptability judgements. However, in light of the corpus data presented in section 3.1, where we see that these colloquial constructions do in fact occur in print, we have to question how important the modality issue is. If it is possible to present participants with multiple n-word constructions in the context of sports reports, or stories that are clearly written in a colloquial tone, one should be able to elicit different acceptance rates. But, as noted, future research will certainly need to 
investigate how willing native speakers are to accept aurally presented multiple n-word constructions.

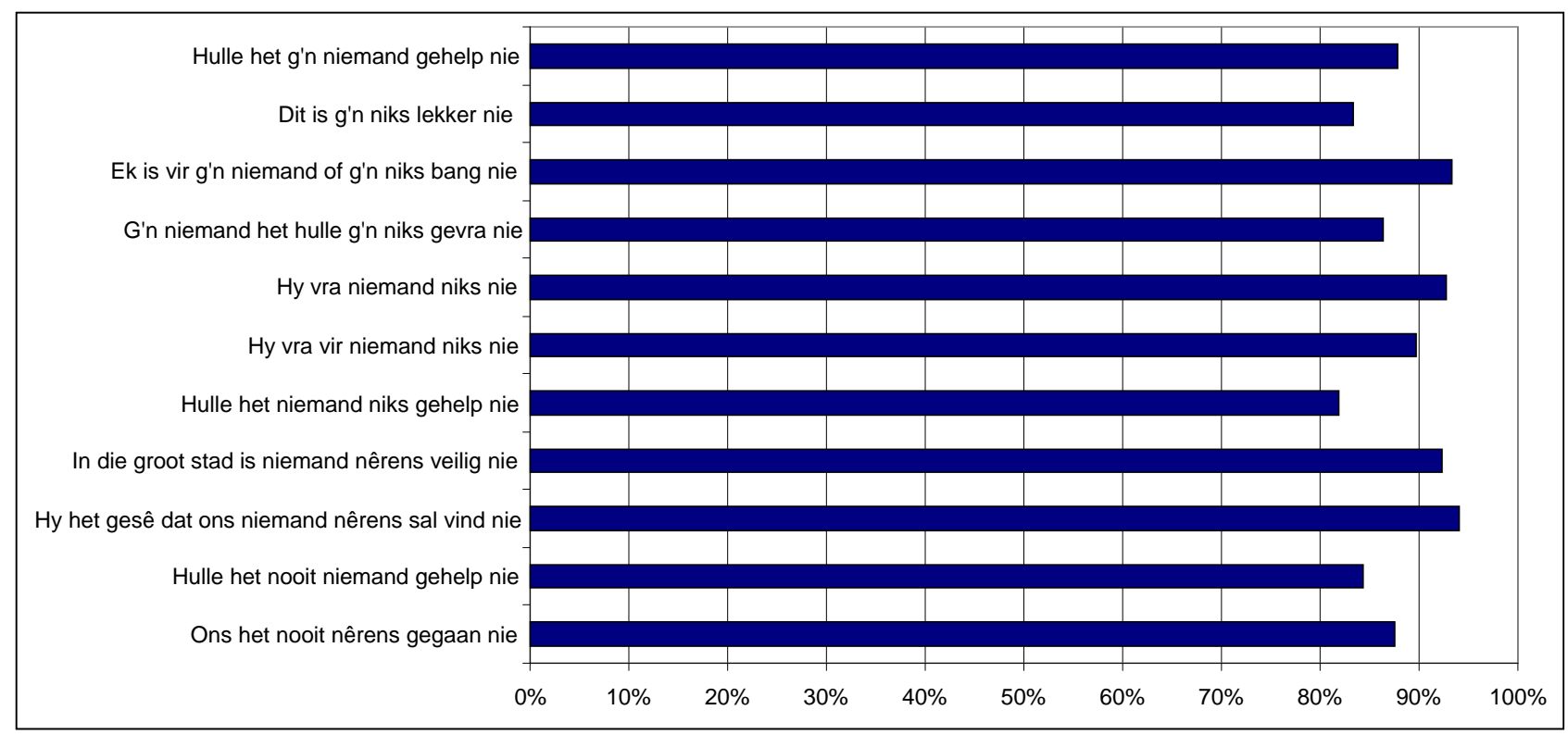

Figure 5. Percentage of participants who chose the negative concord interpretation for sentences that they considered acceptable

Figure 5 is a graph of the participants' responses when asked to give an indication of the meaning of the various sentences. (The percentages given here are only for participants who judged the relevant sentence to be acceptable.) For each of these sentences, the majority of respondents indicated that the negative concord interpretation of the sentence was correct. In the relevant examples in (25) to (39), the negative concord interpretation is represented by the English translation ${ }^{9}$. As mentioned in note 6 , these sentences were presented together with other negative constructions (not containing multiple n-words), however, for some of the sentences given in (25) to (39) only a negative concord interpretation is possible, which may have led to all the sentences containing multiple n-words being biased towards a negative concord interpretation. It is therefore important for future research to involve judgement tasks in which a mix of target and distractor sentences, specific to the phenomenon being investigated, are used. Nevertheless, these findings reinforce the conclusion reached in section 2, namely that multiple n-word constructions in Afrikaans are instances of negative concord. In the next section, two analyses of this phenomenon will be examined and an assessment of what is needed to account for the Afrikaans data will be presented. 


\section{Theoretical accounts of negative spread relevant to Afrikaans}

\section{Negative spread as a PF-phenomenon}

One proposal to deal with constructions containing multiple n-words in Afrikaans is that of Molnárfi (2004). He argues that negative spread and negative concord should be treated as two separate phenomena in Afrikaans. Molnárfi's proposal is that indefinites in Afrikaans may either remain unmarked for negation within the scope of negation as we see in example (40), or they may undergo negative spread, as illustrated by example (41).

(40) ...dat ek nooit iets van iemand gevra het nie.

...that I never anything from anyone asked have NEG

"...that I have never asked anybody for anything"

(41) ...dat ek nooit niks van niemand gevra het nie 2 .

...that I never nothing from no-one asked have NEG

"...that I have never asked for anything from anybody"

(Molnárfi 2004:216)

Molnárfi views n-words in Afrikaans as inherently negative quantifiers, and, following Haegeman (1995), assumes that they are operators with an inherent Neg-feature that, according to the Neg-criterion ${ }^{10}$, has to be licensed in a feature checking relation with a negative head. The structure that he proposes for Afrikaans negative sentences, such as Ek het niemand gesien nie 2 (="I saw nobody"), is reproduced in figure 6 below. 


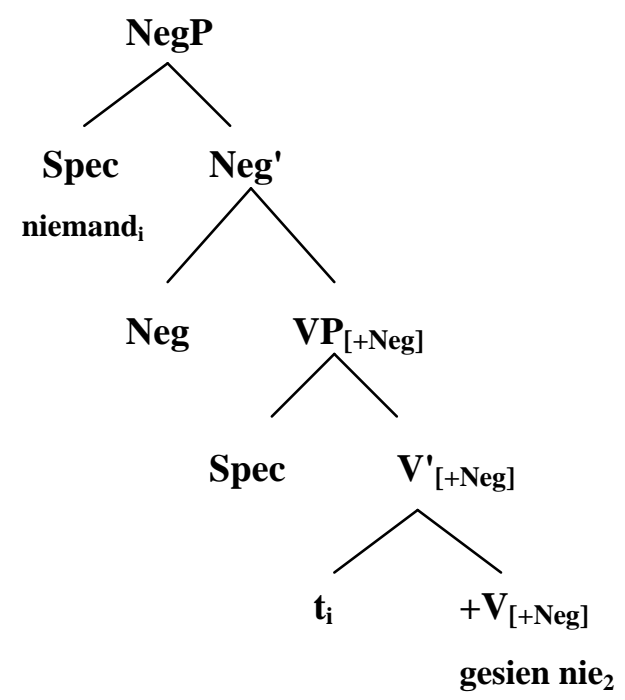

Figure 6. Abstract structure for Afrikaans sentences containing negative quantifiers

His proposal that the occurrence of multiple n-words is the overt Neg-marking of indefinites explains why sentences with multiple VP-internal n-words do not violate the Neg-criterion. The first n-word, or inherently negative quantifier (nooit in example (40)), moves to [Spec, $\mathrm{NegP}]$ in order to check its Neg-feature against the head of $\mathrm{NegP}^{11}$. The other n-words, according to Molnárfi, are just copies of this Neg-feature and are consequently only spelled out after syntax, making negative spread a PF-phenomenon in Afrikaans. Precisely how the Neg-feature becomes part of the feature-bundles that originally occupied the lower positions is not clear, nor is it clear how this feature percolation can be prevented from taking place in other contexts where it would be unnecessary or even unacceptable.

According to this proposal there are thus two types of n-words in Afrikaans, "genuine" negative quantifiers, and forms that look like negative quantifiers but are in fact non-negative indefinites that occur together with a spelled out copy of a negative feature. Molnárfi motivates this analysis on the basis of his theory of the negation bracket in Afrikaans, namely that $n i e_{1}$ opens the domain of negation, and nie $e_{2}$ closes this domain and marks the rightperiphery of the sentence. Molnárfi argues that in Afrikaans the negative domain is infiltrated by silent copies of the first negator $\left(\right.$ nie $\left._{1}\right)$ as a result of top-down feature percolation. Negative concord in Afrikaans is then a result of the "morphological realisation of one or more of the NEG-copies" (Molnárfi 2004:201). In this account, the second negator $\left(\right.$ nie $\left._{2}\right)$ is the spell-out of the lowest NEG-copy. Furthermore, according to Molnárfi, in multiple n-word 
constructions, each silent copy of the negation head is spelled out, and this spelling out of additional copies of negation facilitates parsing in spoken discourse.

Of course, the interpretation of multiple n-words as an instance of single negation is still problematic from the point of view of the principle of compositionality ${ }^{12}$, as Molnárfi's proposal does not cover the interpretation of the multiple spelled-out copies of the negative feature. It is not clear in this account how LF would be able to distinguish the standard Afrikaans (double negation) interpretation of Niemand het niks gedoen nie 2 (="No-one did nothing") from the colloquial (negative concord) interpretation of this sentence (="No-one did anything"). Another problem with this proposal is that if we accept that multiple n-word constructions are the result of a parsing strategy, then there should be extensive negative spread in spoken Afrikaans, which is not the case. Moreover it is not clear what exactly is meant by a 'parsing strategy', as the exact nature of this concept remains vague in Molnárfi's analysis. The availability of a negative concord interpretation for multiple n-word constructions seems more likely to cause confusion rather than aid comprehension, as Molarfi claims. Utterances such as Hy gee niemand niks nie (="He gives nobody anything") are ambiguous in spoken Afrikaans because of the availability of both a negative concord and a double negation interpretation. The same utterance is not ambiguous in standard Afrikaans as the negative concord interpretation is not available, making it more easily understood. So it would appear that far from aiding parsing, the possibility that multiple n-word constructions have a negative concord interpretation makes comprehension more difficult.

Finally, the fact that in this proposal the phenomenon of negative spread is restricted to PF, with negative features only being spelled out after syntax is problematic in the following ways. Molnárfi's proposal cannot account for the fact that indefinites in the scope of negation, such as iets, iemand, etc., are sometimes spelled out as non-negative, rather than being subject to negative spread. Furthermore, according to Molnárfi, indefinites sometimes remain unmarked for negation while sometimes undergo negative spread. However, there is no optionality at PF, which means that there is currently no theory of PF which is compatible with Molnárfi's proposal. 


\section{Emphatic Multiple Negative Expressions (EMNE's) vs. Negative Concord}

Let us now return to Zeijlstra's proposal that combinations of n-words (at least in Dutch and German) can be characterised as EMNE's rather than negative spread. According to Zeijlstra (2006), EMNE's differ from standard negative concord constructions in at least five ways:

(i) EMNE's always have an emphatic reading, while negative concord constructions generally do not.

(ii) The first part of the EMNE must carry stress, otherwise it is ruled out.

(iii) EMNE's are subject to strict adjacency conditions, contrary to negative concord constructions.

(iv) The meaning of an EMNE is not always straightforward, contrary to most negative concord constructions.

(v) The formation of EMNE's is not productive and speakers generally differ with respect to which EMNE's they accept and which they do not.

The question that arises is whether constructions with multiple n-words in Afrikaans exhibit characteristics that Zeijlstra attributes to EMNE's or characteristics of negative concord constructions, and therefore negative spread. Biberauer (this issue) characterises $g^{\prime} n$ niks as a lexicalised reinforced negative, making reference to Zeijlstra's proposal regarding Emphatic Multiple Negation. However, she does not discuss other instances of multiple n-word constructions $^{13}$. The data presented in section 3 could thus be useful in addressing the above question.

Firstly, with regard to emphatic readings of EMNE's (see (i) above), it does appear to be possible to classify instances of multiple n-words in Afrikaans as having an emphatic reading. In most cases where multiple n-words occur native speaker intuitions tell us that a construction has clearly been used for emphasis, especially with regard to constructions containing $g^{\prime} n$ and geen as in sentences (13) and (17), repeated below as (42) and (43). These are clearly examples of emphatic negation, as is sentence (15), repeated as (44), which contains the combination niemand niks. 
(42) Ons het g'n niks deure vir Nicholis Louw oopgemaak nie ${ }_{2}$. we have no nothing doors for Nicholis Louw open-made NEG "We opened no doors for Nicholis Louw."

(Rapport 2005-11-27)

(43) Ek het geen stokperdjies, geen meisies, geen niks nie 2. I have no hobbies no girlfriends no nothing NEG "I have no hobbies, no girlfriends, nothing."

(Die Burger 1998-05-11)

(44) Daarom sê ek, ons skuld niemand niks nie $e_{2}$ ! therefore say I we owe nobody nothing NEG "Therefore I say that we owe nobody anything!"

(Landbouweekblad 2002-10-11)

Of course, although Zeijlstra maintains that negative concord constructions do not usually have an emphatic reading, he does point out that the use of redundant negation always leads to an emphatic effect and that Middle Dutch negative concord constructions, which he claims are predecessors of EMNE's in Dutch, would already have had an emphatic reading. This means that even if all multiple n-word constructions in Afrikaans have an emphatic reading this does not rule out that they may be negative concord constructions. In fact it seems problematic to claim that negative concord constructions do not have an emphatic reading, as this would seem to imply that speakers of negative concord languages are unable to express emphatic negative structures, which is clearly wrong. It appears, therefore, that this aspect of Zeijlstra's proposal is not necessarily useful in distinguishing between EMNE's and negative concord constructions.

The second difference between EMNE's and negative concord, the requirement that the first element of the EMNE carry stress (see (ii) above), is problematic for written data as it is not always possible to determine whether or not stress is intended in the construction. Again, native speaker intuitions lead us to assume that this condition is not always met in Afrikaans, as it is possible to produce some or most of these constructions with no additional stress on 
the first element. In the case of sentences (42) and (43) above, stress must in fact be placed on the second element, leading to $g^{\prime} n$ NIKS and geen NIKS respectively. In certain instances, such as sentence (45), it is possible to stress both negative elements. It is not clear that this issue will be resolved without the collection of spoken data, or at the very least, the solicitation of native speaker judgements of aurally presented sentences and the elicitation of spoken multiple n-word constructions.

(45) Ek het NIEMAND NOOIT aangesê om te lieg nie ${ }_{2}$.

I have nobody never to-said to lie NEG

"I have never told anybody to lie."

(Volksblad 1998-08-17)

Thirdly, with regard to the adjacency condition (see (iii) above), it can be argued that the data presented in this paper does support the conclusion that adjacency is a necessary requirement for multiple n-word constructions in Afrikaans, but this is partly a result of the data collection process. The corpus searches were only conducted for adjacent n-words and sentences tested in the sentence judgement study also only contained adjacent n-words. In order to determine whether the adjacency condition really holds it is necessary to conduct more comprehensive searches of the database, to determine whether these multiple n-word constructions can in fact occur with intervening material, and to test native speaker judgements of such sentences. Native speaker intuitions tell us, though, that these constructions are unlikely to be subject to a strict adjacency condition. Since sentences such as sentence (8) in section 1, repeated below as (46), where an auxiliary intervenes between two n-words, are completely acceptable in colloquial varieties of Afrikaans. It is likely that sentences that contain additional intervening material would also be acceptable. The constructions that, at first glance, do appear to be subject to a strict adjacency condition are those in which the first negative element is a negative determiner, i.e. $g^{\prime} n$ and geen, but even here expletive insertion is possible as sentence (47) illustrates ${ }^{14}$.

(46) Niemand het niks gedoen nie 2 . nobody have nothing done NEG "Nobody did anything." 
(47) Ek het g'n bleddie niks gesien nie 2.

I have no bloody nothing seen NEG

"I saw absolutely nothing."

With regard to the fourth difference, which is largely concerned with the idiosyncratic nature of EMNE's (see (iv) above), it is clear that this characteristic does not hold for the Afrikaans data. Looking at the various examples of multiple n-word combinations found in the corpus, it is clear that their meaning is indeed predictable, that is, the meaning is compositionally derived and the meaning of a sentence containing two n-words corresponds to the meaning of the sentence in which the second negative element is replaced by its non-negative counterpart, or, in the case of $g^{\prime} n$ or geen by a zero-determiner. This is also the case for the responses from the speaker judgement study. As pointed out, the majority of respondents who judged a multiple n-word construction to be acceptable interpreted the sentence as conveying a negative concord meaning.

With regard to the fifth difference, namely productivity (see (v) above), most possible combinations of $n$-words are attested in the corpus data, with the exception of combinations of n-words in which $g^{\prime} n$ or geen is the second word ${ }^{15}$, and four other combinations of n-words, namely, niks niemand, nêrens niemand, nêrens niks and niks nooit. With regard to the first two combinations, niks niemand and nêrens niemand, the reason for their absence in the corpus can be explained by the fact that these combinations are, in fact, ungrammatical, as niemand requires the preposition vir to precede it when it remains in situ, as is shown in sentences (48) and (49).

(48) Hy gee niks *(vir) niemand (nie 2 ).

he gives nothing for nobody NEG

"He gives nothing to anybody."/"He doesn't give anything to anybody."

(49) Hy sien nêrens *(vir) niemand (nie 2$)$.

he sees nowhere for nobody NEG

"He sees nobody anywhere."/"He doesn't see anybody anywhere." 
This observation is borne out by the data from the native speaker judgement study. In the responses to the questionnaire, the combinations judged unacceptable by the majority of the participants were niks niemand, nêrens niemand, nêrens nooit and niemand nooit. Again, the unacceptability of the first two combinations, niks niemand and nêrens niemand, can be attributed to their ungrammaticality, as illustrated in sentences (48) and (49). This means that sentences (32) and (35) in section 3.2. above, where vir is absent, are in fact ungrammatical, and so it is no surprise that they were judged unacceptable by the majority of the participants. As pointed out in the discussion of the adjacency condition above, more comprehensive searches of the database are necessary in order to determine whether multiple n-word constructions can in fact occur with intervening material, as is the case in sentences (48) and (49), and to test native speaker judgements of such sentences. With regard to the second two combinations, nêrens nooit and niemand nooit, discussions with native speakers of Afrikaans seem to indicate that there are structures in which these orderings would be able to give rise to a negative concord interpretation, consider, for example, sentences (50) and (51).

(50) Hy gee niemand nooit 'n kans nie. he gives nobody never a chances NEG "He never gives anybody a chance."/"He gives nobody a chance ever."

(51) Hy's nêrens nooit tevrede nie 2. he's nowhere never satisfied NEG "He's never satisfied anywhere."

As for the second two combinations not attested in the corpus, nêrens niks and niks nooit, it is not clear that the absence of these constructions makes them necessarily unacceptable to native speakers of Afrikaans. As with the two constructions in (50) and (51), native speaker judgements of such sentences, presented aurally, are necessary before one can rule them out categorically. Of course the fact that certain combinations of n-words may be more acceptable than others does not necessarily rule out negative concord since some kind of semantic/pragmatic restriction on the ordering of n-word combinations could be at issue here. 
Zeijlstra's proposal is that, due to their idiosyncratic nature, EMNE's are in fact lexical items despite their complex appearance. He takes EMNE's to be single lexical items that consist of two different semantic objects: a negative indefinite and an additional non-negative indefinite or negative marker, resulting in the entire EMNE containing only one negation.

(52) Nooit geen:
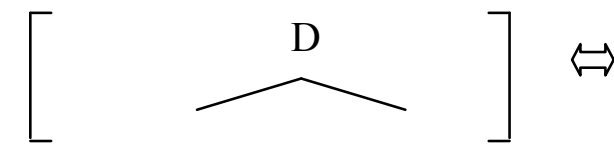

/nooit geen/

\section{Adv: NEVER D: A/AN}

(Zeijlstra 2006: 6)

This does not appear to be the correct analysis for multiple n-words in Afrikaans. These constructions do not sufficiently fulfil Zeijlstra's conditions for EMNE's as I have shown in the preceding discussion. Even if we only consider constructions containing $g$ 'n (and geen), which appear to display some of the differences that Zeijlstra notes between EMNE's and negative concord constructions, namely that they always have an emphatic reading and they are subject to strict adjacency conditions, it is unlikely that these are lexical items. Crucially these constructions fail the criterion that the first part of an EMNE must carry stress. In fact, if the first part of the constructions is stressed, e.g. G'N niks, we either get a double negation reading (="no nothing"), or $g^{\prime} n$ has to be interpreted as contributing the meaning of an independent nie as is illustrated by sentence (53), which has the same structure as the sentence in (54). In this case $g^{\prime} n$ functions as a separate element, and so cannot have the structure illustrated in (52).

(53) Hy het G'N niks gedoen nie 2 . he have no nothing done NEG "He has done absolutely nothing."

(54) Hy het G'N die boek gelees nie 2 . he have no the book read NEG "He hasn't read the book at all." 
What is perhaps the case with, specifically, $g^{\prime} n$ niks, is that this combination has become conventionalised, and is, in this way, distinguished from other n-word combinations. This analysis is supported by sentence (55) in which $g^{\prime} n$ niks occurs together with a third n-word nêrens. In this case it appears that $g^{\prime} n$ niks forms a collocational unit as it can be replaced as a whole by another intensifier, such as glad (see (56a)), but $g^{\prime} n$ and niks cannot separately be replaced by such an intensifier, (see $(56 \mathrm{~b}$ and $\mathrm{c})$ ). This analysis is further supported by the corpus data, where g'n niks was the most frequently occurring n-word combination, despite the fact that $g^{\prime} n$ was the second lowest occurring n-word in the corpus. However, it is important to note that the other n-word combinations discussed in this paper do in fact appear to be true negative concord constructions (i.e. negative spread constructions), so that at the very least there are two types of constructions that contain multiple n-words in colloquial Afrikaans, namely, collocational negative concord constructions, such as $g^{\prime} n$ niks, and negative concord/negative spread constructions, such as niemand niks. There is of course a third possibility, namely that multiple n-word constructions are interpreted as instances of double negation, as is the case in standard Afrikaans.

... en sê hy gaang'n niks nêrens nie , hy is 'n Afrikaner.

... and said he goes no nothing nowhere NEG he is an Afrikaner

"... and said he isn't going anywhere at all, he's an Afrikaner."

(Beeld 2006-09-28)

(56) (a) Hygaan glad nêrens nie 2 .

he goes altogether nowhere NEG

"He goes absolutely nowhere."

(b) *Hy gaan glad niks nêrens nie 2 .

he goes altogether nothing nowhere NEG

(c) *Hy gaan g'n glad nêrens nie 2 .

he goes no altogether nowhere NEG

Finally, Zeijlstra's argument for the existence of EMNE's in Dutch does not appear to be applicable to Afrikaans. Zeijlstra maintains that the analysis of multiple n-word constructions as lexical items (EMNE's) is a result of the fact that Dutch is no longer a negative concord 
language. The inability of (first language) learners of Dutch to interpret multiple n-word constructions as instances of negative concord led to the analysis of these constructions as lexical items as a last resort option. However, Zeijlstra's conclusion that these constructions are the remnant of what was previously a negative concord language (Middle Dutch) cannot hold for Afrikaans which is at present a negative concord language. In fact, the data presented (in section 3) above leads us to the opposite prediction for negative spread in Afrikaans. Negation in Standard Afrikaans consists of nie 1 (or an n-word) occurring together with nie. If the occurrence of multiple n-words with a negative concord reading is becoming more prevalent in colloquial varieties of Afrikaans, then the reverse development to that seen in Dutch is taking place and negative spread is becoming part of the (spoken) language.

\subsection{Assessment of Afrikaans data}

The results of the data collection reported in this paper show that in non-standard, colloquial varieties of Afrikaans, there are constructions in which more than one n-word occurs together with the sentence-final nie 2 yielding a negative concord interpretation. Although these constructions are not acceptable in Standard Afrikaans it is still necessary to provide an analysis and an explanation for these constructions as they occur in colloquial spoken Afrikaans. From the preceding discussion of Molnárfi's (2004) analysis of negative spread in Afrikaans and Zeijlstra's (2006) analysis of emphatic negation in Dutch, a language closely related to Afrikaans, it is clear that existing analyses are not sufficient to account for the Afrikaans data.

This paper does not intend to provide an alternative analysis, but attempts to provide an empirically based description of multiple n-word constructions in Afrikaans in order to highlight the relevant research questions and identify what further data are needed to facilitate the development of a theory to account for multiple n-word constructions in Afrikaans. With regard to the relevant research questions, it is evident that the development of a typology of nword combinations in Afrikaans is necessary as all combinations do not appear to be equivalent in terms of acceptability. Only then will it be possible to determine whether the intuition that n-word combinations in Afrikaans exist on some sort of continuum from those combinations which appear to be largely lexicalised to those which are clear examples of negative spread, is accurate. 
The quantificational status of n-words in Afrikaans is also relevant to a study of multiple nword combinations as they pose a puzzle from a semantic point of view, that is, they raise problems for the principle of compositionality of meaning which holds that the meaning of a complex expression is derivable from the meaning of its immediate constituents, and the way they are combined. Various proposals have been put forward in the literature, which can be characterised in terms of three approaches. Firstly, n-words are seen as non-negative existential or universal quantifiers (Laka 1990; Ladusaw 1992; Giannakidou 1997, 2000), or as non-negative indefinites (Zeijlstra 2004). A second type of analysis characterises n-words as underspecified, i.e. compatible with both a negative quantifier and an existential quantifier meaning (Van der Wouden and Zwarts 1993; Van der Wouden 1994; Herburger 2001; Giannakidou 2006). Finally, the negative quantifier approach takes n-words to be inherently negative quantifiers (Zanuttini 1991; Haegeman and Zanuttini 1991, 1996; Haegeman 1995; De Swart and Sag 2002; Watanabe 2004; De Swart 2006). This last approach is the one that seems to account best for Standard Afrikaans, where multiple n-word constructions are (prescriptively) not acceptable. However, the question of n-word status is more problematic for non-standard varieties of Afrikaans that contain multiple n-word constructions and this has to be considered if one wishes to achieve a comprehensive analysis of negation in Afrikaans.

It is clear that further data collection is essential if these, and other questions, are to be answered. Firstly, as mentioned before, the elicitation of spoken sentences containing multiple n-words, as well as native speaker judgements of such spoken sentences, is necessary in order to evaluate the stress and intonation patterns of multiple n-word combinations in Afrikaans. Ideally one would want to conduct a search of spoken language corpora for Afrikaans to determine the extent to which these constructions occur in standard and non-standard spoken varieties of Afrikaans, something which is currently restricted by the paucity of such resources.

As noted previously, more comprehensive searches of the written corpora available through Media24 are necessary in order to answer questions about the frequency of multiple n-word combinations, in terms of word counts, and the possibility and nature of adjacency constraints on n-words occurring together. It would also be particularly interesting to conduct searches related to the co-occurrence of n-words and negative polarity items (NPIs), such as enige 
iemand, enige iets and ooit, and the co-occurrence of n-words and non-negative indefinites, such as iemand, iets and êrens. This would enable us to determine how frequent multiple nword constructions are in comparison to constructions containing a combination of a single $n$ word with (a) non-negative indefinite(s) or (an) NPI(s), which could, in turn, indicate whether multiple n-word constructions are becoming more prevalent in the written corpus. The results of such research could yield predictions with regard to the diachronic development of Afrikaans as a negative concord language.

\section{Conclusion}

This paper has provided an empirically based description of Afrikaans negative concord constructions in which multiple n-words occur together with the sentence-final nie 2 . Firstly, a definition of the phenomenon in question, known generally as negative spread, was given. The empirical data, in the form of a corpus study and a sentence judgement study, were then presented and analysed. A critical examination of two proposed analyses of the phenomenon was subsequently undertaken, followed, finally, by an assessment of what is needed to account for the Afrikaans data discussed in the paper. It is clear that a significant amount of research is still needed if a comprehensive analysis of this phenomenon in Afrikaans is to be achieved. Hopefully, this article has, in its investigation of a relatively large set of data, provided some avenues for future research on the phenomenon.

\section{Notes}

* I would like to thank two SPIL reviewers for their helpful suggestions and comments, as well as Henriëtte de Swart for her insightful guidance and Theresa Biberauer for stimulating and motivating discussions. Any errors that remain are, of course, my own. This material is based upon work supported by the South African National Research Foundation. Any opinion, findings and conclusions or recommendations expressed in this material are those of the author and do not necessarily reflect the views of the National Research Foundation.

1. Negative concord is typical of the Romance languages, such as French and Italian, but it is not common in West Germanic languages, although see (Haegeman 1995) for a 
description of negative concord in West Flemish, and (Bayer 1990) and (Weiss 2002) for descriptions of negative concord in Bavarian.

2. Giannakidou (2006: 328) defines the set of expressions known as n-words as follows An expression $\alpha$ is an n-word iff:

(a) $\alpha$ can/must be used in structures containing sentential negation or another $\alpha$ expression yielding a reading equivalent to one logical negation; and

(b) $\alpha$ can provide a negative fragment answer.

(It is important to note that negative morphology is not a prerequisite for n-word status.)

3. The first, and most detailed, description of Afrikaans within a broad generative approach is (Waher 1978). There are other descriptions of negation in Afrikaans, for example (Ponelis 1979, 1993), (De Stadler 1989) and (Donaldson 1993), however, these are very general and non-generative in nature. More recent contributions to this field include (Robbers 1992), (Oosthuizen 1998), (Molnárfi 2002, 2004), (Bell 2004) and (Biberauer 2007). See also (Den Besten 1986) and (Roberge 2000) for discussions of the origin of negative concord in Afrikaans.

4. In more formal (written) registers it would also be possible to emphasise or reinforce the negation in a sentence like (10) using intensifiers such as glad, hoegenaamd or absoluut, as in the following sentence:

(a) Jy gaan met hierdie ding absoluut nêrens kom nie 2 . you go with this thing absolutely nowhere come NEG "You won't get anywhere at all with this thing."

5. Future corpus-based research on this topic is planned in order to address these possible shortcomings in the accuracy of the results.

6. An anonymous reviewer pointed out that this could also be an indication that $g^{\prime} n$ is becoming standardised.

7. These sentences formed part of a larger pilot study conducted to elicit native speaker judgements on a variety of Afrikaans negative sentences. The pilot study was divided into two separate parts. The first part consisted of 79 Afrikaans sentences, aimed at testing the possible positions of nie $e_{1}$ and $n_{i} e_{2}$. The second part consisted of 37 Afrikaans sentences, which were a mixture of emphatic negation constructions, multiple n-word constructions and negative fragment answer constructions. 
8. A translation of the example question follows:

47. (Points: 0 )

Is dit aanvaarbaar vir 'n Afrikaanssprekende om die volgende te sê?

"Is it acceptable for an Afrikaans-speaking person to say the following?" Indien wel, dui dan in die volgende vraag aan wat die sin beteken.

"If so, indicate in the following question what the sentence means."

Hulle het g'n niemand gehelp nie

hulle have no nobody helped NEG

"They didn't help anybody at all."

$$
\begin{aligned}
& \text { 1. Ja } \\
& \text { "Yes" } \\
& \text { 2. Nee } \\
& \text { "No" } \\
& \text { 3. Nie seker nie } \\
& \text { "Not certain" }
\end{aligned}
$$

\section{Save Answer}

48. (Points: 0)

Beskou weer die voorbeeld sin by die vorige vraag:

"Consider again the example sentence from the previous question:"

\section{Hulle het g'n niemand gehelp nie}

hulle have no nobody helped NEG

"They didn't help anybody at all."

Indien hierdie sin aanvaarbaar is, gee ' $n$ aanduiding van wat dit beteken.

"If this sentence is acceptable, give an indication of what it means.

a. Hierdie sin is nie aanvaarbaar vir 'n Afrikaanssprekende nie.

"This sentence is not acceptable for an Afrikaans-speaking person."

b. Dit beteken dat hulle geeneen gehelp het nie.

"It means that they didn't help anyone."

c. Dit beteken dat hulle wel iemand gehelp het.

"It means that the did help someone."

d. Dit kan enige een van hierdie betekenisse hê, afhangende van die konteks.

"It can have either one of these meanings, depending on the context."

Save Answer

9. It is possible for some of these sentences to be interpreted with a double negation meaning, as would be the case in Standard Afrikaans, however I have not provided translations that correspond to the double negation interpretation, as the focus of this paper is on the negative concord interpretation of multiple n-word constructions. An example of a double negation interpretation would be as follows:
(a)
A: Ek dink dis niks
lekker nie ${ }_{2}$.
B: Nee, dit is g'n niks
lekker nie .
I think it's nothing nice NEG
No it is no nothing nice NEG
A: "I think it's not nice"
B: "No, it is not true that it is not nice." 
10. The NEG-criterion can be formulated as follows -

(a) Each Neg $\mathrm{X}^{\mathrm{O}}$ must be in a Spec-Head relation with a Negative phrase

(b) Each Negative phrase must be in a Spec-Head relation with a $\mathrm{Neg} \mathrm{X}^{\mathrm{O}}$

(Haegeman and Zanuttini 1996: 153)

11. As pointed out by a reviewer, it is worth noting that there does not appear to be any evidence that n-words in Afrikaans have to raise to [Spec, NegP]. See (Biberauer 2007) for a discussion of the empirical facts that call into question whether it is necessary to postulate a NegP for Afrikaans, in the manner that Molnárfi does. For theoretical arguments against postulating an NegP for Germanic languages (including Afrikaans) see (Zeijlstra 2004), and for arguments against the existence of an NegP see (Breitbarth 2007).

12. The principle of compositionality of meaning states that the meaning of a complex expression is derivable from the meaning of its immediate constituents.

13. In fact, Biberauer (p.c.) indicates that she does not think multiple n-word constructions are generally lexicalised, contra Zeijlstra (2006), with the possible exception of $g$ 'n niks.

14. Although, as Theresa Biberauer who provided this example, points out, the expletive insertion facts do not definitively indicate that $g^{\prime} n$ niks is not a single lexical item.

15. This is related to the fact that $g^{\prime} n$ and geen are intensifiers, along with items such as glad, hoegenaamd and absoluut (see note 4).

\section{References}

Bayer, J. 1990. What Bavarian Negative Concord reveals about the syntactic structure of German. In J. Mascaró and M. Nespor (eds). Grammar in Progress. Dordrecht: Foris. pp. 13-23.

Bell, A. 2004. How N-words move: Bipartite negation and 'Split-NegP'. In A. Breitbarth and H. van Riemsdijk (eds). Triggers. Amsterdam: Mouton de Gruyter. pp. 77-114.

Biberauer, T. 2007. Afrikaans negation as a clause-structure diagnostic. To appear in Nanzan Papers in Linguistics.

Biberauer, T. (this issue) A closer look at Negative Concord in Afrikaans. Stellenbosch Papers in Linguistics Plus 35: 1-52. 
Breitbarth, A. 2007. About NegP. Manuscript, Cambridge University. Available on-line at: http://people.pwf.cam.ac.uk/ab667/papers/AboutNegP.pdf.

Den Besten, J.B. 1986. Double negation and the genesis of Afrikaans. In P. Muysken and N. Smith (eds). Substrata versus universals in Creole languages. Amsterdam: John Benjamins. pp. 185-230.

De Stadler, L.G. 1989. Afrikaanse Semantiek. Johannesburg: Southern Boekuitgewers.

De Swart, H. 2006. Expression and Interpretation of Negation. Manscript, Utrecht University. Available on-line at http://www.let.uu.nl/ Henriette.De Swart/personal/Negot/ negotbook.htm.

De Swart, H. and I.A. Sag. 2002. Negation and Negative Concord in Romance. Linguistics and Philosophy 25: 373-417.

Donaldson, B.C. 1993. A grammar of Afrikaans. Berlin: Mouton de Gruyter.

Giannakidou, A. 2006. N-words and Negative Concord. In M. Everaert and H. van Riemsdijk (eds). The Blackwell Companion to Syntax. Oxford: Blackwell. pp. 327-391.

Giannakidou, A. 2000. Negative...Concord? Natural Language and Linguistic Theory 18: 457-523.

Giannakidou, A. 1997. The landscape of polarity items. Doctoral dissertation, Rijksuniversiteit Groningen

Haegeman, L. 1995. The syntax of negation. Cambridge: Cambridge University Press.

Haegeman, L. and R. Zanuttini. 1996. Negative concord in West Flemish. In A. Belletti and L. Rizzi (eds). Parameters and functional heads. Essays in comparative syntax. Oxford: Oxford University Press. pp. 117-179.

Haegeman, L. and R. Zanuttini. 1991. Negative heads and the Neg Criterion. The Linguistic Review 8: 233-251.

Herburger, E. 2001. The Negative Concord puzzle revisited. Natural Language Semantics 9: 289-333.

Hoeksema, J. 1997. Three systems of negative concord. Manuscript, Rijksuniversiteit Groningen.

Labov, W. 1972. Negative Attraction and Negative Concord in English grammar. Language 48: $773-818$. 
Ladusaw, W.A. 1992. Expressing negation. In C. Barker and D. Dowty (eds.) Proceedings from the second conference on Semantics and Linguistic Theory. Working Papers in Linguistics 40. Columbus: Ohio State University. pp. 237-259.

Laka, I. 1990. Negation in syntax: On the nature of functional categories and projections. Doctoral dissertation, MIT.

Media24. 2007. Archive. Available on-line at http://152.111.1.251/index.html. Accessed on 8 February 2007.

Molnárfi, L. 2002. Die Negationsklammer im Afrikaans. Mehrfachnegation aus formaler und funktionaler Sicht. In W. Abraham and C.J-W. Zwart (eds). Issues in formal Germanic typology. Amsterdam: John Benjamins. pp. 223-261.

Molnárfi, L. 2004. On the interpretation of multiple negation in spoken and written Afrikaans. In A. ter Meulen and W. Abraham (eds). The composition of meaning. From lexeme to discourse. Amsterdam: John Benjamins. pp. 195-225.

Murphy, V. 1997. The effect of modality on a grammaticality judgement task. Second Language Research 13: 34-65.

Oosthuizen, J. 1998. The final nie in Afrikaans negative sentences. Stellenbosch Papers in Linguistics 31: 61-93.

Ponelis, F.A. 1978. Afrikaanse Sintaksis. Pretoria: J.L. van Schaik.

Ponelis, F.A. 1993. The development of Afrikaans. Frankfurt am Main: Lang.

Robbers, K. 1992. Properties of negation in Afrikaans and Italian. In R. Bok-Bennema and R. van Hout (eds). Linguistics in the Netherlands. Amsterdam: John Benjamins. pp. 223-234.

Roberge, P. 2000. Etymological opacity, hybridization, and the Afrikaans brace negation. American Journal of Germanic Linguistics and Literatures 12: 101-176.

Van der Wouden, T. 1994. Negative contexts. Doctoral dissertation, Rijksuniversiteit Groningen.

Van der Wouden, T. and F. Zwarts. 1993. A semantic analysis of negative concord. Semantics and Linguistics Theory (SALT) III: 202-219.

Waher, H. 1978. Die probleem van die bereik van die ontkenning met spesiale verwysing na Afrikaans. Doctoral dissertation, University of Cape Town.

Watanabe, A. 2004. The genesis of Negative Concord: Syntax and morphology of Negative Doubling. Linguistic Inquiry 35: 559-612. 
Weiss, H. 2002. Three types of negation - A case study in Bavarian. In J. Barbiers (ed). Syntactic Microvariation. Available on-line at http://www.meertens.knaw.nl/ projecten/sand/synmic/

Zanuttini, R. 1991. Syntactic properties of sentential negation. A comparative study of Romance languages. Doctoral dissertation, University of Pennsylvania.

Zeijlstra, H. 2006. Emphatic Multiple Negative Expressions in Dutch-A by-product of loss of negative concord. Available on-line at http://www.meertens.knaw.nl/projecten/ edisyn/Onling proceedings/Paper Zeijlstra.pdf.

Zeijlstra, H. 2004. Sentential negation and negative concord. Doctoral dissertation, Universiteit van Amsterdam. 